\title{
HUBUNGAN PENGETAHUAN, SARANA PRASARANA, DAN PENGAWASAN DENGAN PERILAKU PENERAPAN SOP PEKERJA CONFINED SPACE
}

\author{
RELATIONSHIP BETWEEN KNOWLEDGE, FACILITIES, AND \\ SUPERVISION WITH IMPLEMENTATION BEHAVIORS OF SOP CONFINED \\ SPACE WORKERS
}

\author{
Ratih Putri Ramadhani \\ PT Atsuka Engineering Indonesia \\ E-mail: rputrirmdhni@gmail.com
}

\begin{abstract}
Working in confined space has very high risks, therefore, one of the hierarchy control to manage identified risk is administrative by implementing Standard Operating Procedures (SOP). The implementation of SOP correlates with the worker behaviors. The purpose of this research is to find out correlation between knowledge, facilities, and supervision to implementation behaviors of sop in confined space. This study is an observational descriptive research using cross sectional approach. The subject is a total population of 19 cleaning workers in Ducting Dust Collector PT. X. The data provided in distribution of frequency tables and was analyzed using crosstabulation followed with Phi and Cramers V Coefficient to see the relation strength. The result of the study shows that most of the workers has a good behavior in implementing the working SOP in confined space. According to Phi and Cramers V Coefficient, Knowledge (0.57) and Facilities (0.57) has a strong relation with the implementation behavior of SOP in confined space. Supervision has no relationship at all with the implementation behavior of working SOP within the confined space.
\end{abstract}

Keywords: behavior, confined space, SOP

\begin{abstract}
ABSTRAK
Pekerjaan yang dilakukan di confined space memiliki risiko bahaya yang tinggi. Salah satu upaya pengendalian risiko yang dapat dilakukan secara administratif dengan menerapkan Standar Operasional Prosedur (SOP). Penerapan SOP berkaitan dengan perilaku pekerja. Tujuan penelitian ini adalah mengetahui hubungan pengetahuan, sarana prasarana, pengawasan dengan perilaku penerapan SOP bekerja di Confined Space. Penelitian ini merupakan penelitian deskriptif dengan rancangan cross sectional dan bersifat observasional. Subjek penelitian ini adalah total populasi sejumlah 19 pekerja cleaning di Ducting Dust Collector PT. X. Hasil penelitian disajikan dalam bentuk tabel distribusi frekuensi dan tabulasi silang disertai koefisien korelasi Phi and Cramers $V$ untuk mengetahui kuat hubungan antar variabel. Hasil penelitian menunjukkan bahwa sebagian besar pekerja telah berperilaku baik dalam menerapkan SOP bekerja di confined space. Berdasarkan nilai koefisien korelasi Phi and Cramers V diketahui bahwa pengetahuan $(0,57)$ dan sarana prasarana $(0,57)$ memiliki hubungan kuat dengan perilaku penerapan SOP bekerja di confined space. Pengawasan tidak memiliki hubungan dengan perilaku penerapan SOP bekerja di confined space.
\end{abstract}

Kata kunci: confined space, perilaku, SOP

\section{PENDAHULUAN}

Confined space adalah ruangan yang cukup besar bagi pekerja untuk dimasuki sebagian maupun seluruh badannya dalam rangka melaksanakan pekerjaan di dalamnya. Ruangan ini memiliki keterbatasan akses keluar-masuk karena memang tidak didesain sebagai tempat kerja dengan pekerjaan yang dilakukan secara terus-menerus (OSHA, 2004).
Pada kondisi tertentu, pekerja perlu masuk di confined space untuk melakukan inspeksi, perawatan, perbaikan, pembersihan atau pekerjaan lainnya yang terkadang sulit dan berbahaya dikarenakan keberadaan faktor-faktor bahaya di dalamnya. Ted A. Pettit dan Richard Braddee, 1994 dalam program safety research oleh NIOSH mengemukakan bahwa bahaya dalam confined space ditentukan oleh materi yang disimpan atau digunakan, proses pekerjaan 
yang berlangsung didalamnya, dan kondisi eksternal di sekitar confined space. Potensi bahaya pekerjaan di confined space meliputi atmosfer berbahaya, substansi berbahaya, konfigurasi, dan energi.

Potensi bahaya yang ada menyebabkan pekerjaan yang dilakukan di confined space memiliki risiko yang tinggi. Pekerja berisiko mengalami kecelakaan mulai dari nearmiss hingga fatality. Studi yang dilakukan pada tahun 2006 oleh sebuah perusahaan California, ditemukan bahwa sekitar seperlima dari insiden ruang terbatas mengakibatkan kematian.

Berdasarkan OSHA Statistics, terdapat 431 insiden confined space dengan 530 kematian di AS akibat kekurangan oksigen dan / atau atmosfer beracun 1992-2005. Pada 18 Agustus-31 Desember 2009, terdapat 36 korban meninggal dunia dan 6 orang dirawat di rumah sakit akibat pekerjaan di confined space. Pada tahun 2010, ada 63 korban meninggal dunia dan 28 orang harus rawat inap. Pada 1 Januari-1 Agustus 2011, ada 22 korban meninggal dunia dan 3 orang rawat inap.

Laporan yang dihimpun oleh Malaysia's Social Security Organisation (SOSCO) menyatakan bahwa pada tahun 2010 terdapat 1.396 kecelakaan yang terjadi di confined space. Kasus kecelakaan confined space di Australia mengakibatkan 8 kematian dan di UK mengakibatkan 29 kematian pada tahun 20032011 (Fishwick, 2012).

Kasus kecelakaan pada pekerjaan confined space juga terjadi di Indonesia. Pada tahun 2011, kecelakaan terjadi di PT. Pertamina (Persero) Refinery Unit IV Cilacap. 7 pekerja jatuh ke dalam tangki penampungan lumpur minyak yang mengakibatkan 4 pekerja meninggal dan 3 pekerja lainnya kritis. Sedangkan, pada tahun 2015 terdapat kecelakaan saat penggantian filter di dalam Gas Turbine Generator (GTG ) PT. X Jabung.

Riset National Safety Council (NSC) menyatakan bahwa kecelakaan kerja terjadi akibat adanya $88 \%$ unsafe behavior, $10 \%$ unsafe condition, dan 2\% tidak diketahui penyebabnya. Oleh karena itu, untuk meminimalisir angka kecelakaan yang disebabkan oleh unsafe behavior maka diperlukan suatu Standar Operasional Prosedur (SOP) dalam melakukan pekerjaan, dalam rangka memberikan jaminan perlindungan terhadap pekerja dan asset lainnya.

Standar Operasional Prosedur (SOP) adalah dokumen tertulis yang memuat prosedur kerja secara rinci, tahap demi tahap dan sistematis.
Tujuan pembuatan SOP yakni agar semua pekerja memiliki persepsi serta standard yang sama saat akan melakukan suatu pekerjaan, sehingga kesalahan dalam melakukan pekerjaan dapat diperkecil. Implementasi SOP yang baik, akan menunjukkan konsistensi hasil kinerja, hasil produk, dan proses pelayanan yang kesemuanya mengacu pada kemudahan karyawan dan kepuasan pelanggan (Dwihardo, 2011).

Proses produksi billet dan coil yang berlangsung di PT. X melibatkan 20 area yang telah teridentifikasi sebagai confined space. Semua area tersebut telah memiliki IBPR (Identifikasi Bahaya dan Penilaian Risiko). Hasil identifikasi bahaya dan penilaian risiko menggambarkan bahwa semua area confined space di PT. X berada pada kategori high atau tinggi.

Upaya pengendalian risiko telah dilakukan untuk mengatasi tingginya risiko pekerjaan di confined space, salah satunya dengan membuat SOP bekerja di confined space. Pelaksanaannya di lapangan masih terdapat beberapa pelanggaran terkait SOP yang ada. Berdasarkan hal tersebut, perlu dilakukan penelitian mengenai faktor apa sajakah yang berhubungan dengan perilaku pekerja dalam menerapkan SOP bekerja di confined space.

Determinan perilaku Notoatmojo (2014) meliputi predisposing factor, enabling factor, dan reinforcing factor. Sehingga peneliti ingin mengetahui hubungan pengetahuan sebagai predisposing factor, sarana prasarana sebagai enabling factor, dan pengawasan sebagai reinforcing factor dengan perilaku penerapan SOP bekerja di confined space.

\section{METODE}

Metode penelitian ini merupakan penelitian deskriptif yaitu penelitian yang bertujuan untuk mendapatkan gambaran suatu keadaan secara objektif. Ditinjau dari waktu pengambilan data, termasuk penelitian cross sectional yaitu penelitian yang dilakukan pada satu waktu dan satu kali yang bertujuan untuk mencari hubungan antara variabel independen dengan variabel dependen. Serta pengambilan data bersifat observasional yaitu penelitian ini hanya mengamati saja tanpa melakukan intervensi.

Populasi dalam penelitian ini adalah seluruh pekerja yang melakukan pekerjaan di confined space area Ducting Dust Collector PT. X pada bulan April 
tahun 2017 sejumlah 19 orang. Sampel ditentukan dengan menggunakan teknik non probability sampling. Hal ini dikarenakan penelitian bersifat deskripstif, tidak menggunakan uji statistik, dan tidak bertujuan untuk generalisasi. Besar sampel penelitian sejumlah total populasi yaitu 19 orang.

Lokasi pengambilan data penelitian ini adalah PT. X yang bergerak pada industri baja. Waktu penelitian ini dimulai Desember 2016-Juni 2017. Pengambilan data dilakukan pada April-Mei 2017. Variabel dependen dalam penelitian ini adalah Perilaku penerapan Standar Operasional Prosedur bekerja di confined space. Variabel independen yang diteliti yaitu predisposing factor (pengetahuan), enabling factor (sarana prasarana), dan reinforcing factor (pengawasan).

Cara pengumpulan data menggunakan data primer dan sekunder. Data primer diperoleh melalui pengisian kuesioner oleh pekerja confined space area Ducting Dust Collector PT. X. Serta, melakukan observasi pada ketersediaan sarana dan prasarana terkait penerapan SOP bekerja di confined space. Data sekunder diperoleh dari dokumentasi atau datadata PT. X meliputi gambaran umum perusahaan, upaya pengendalian risiko bahaya pekerjaan di confined space, dan SOP bekerja di confined space.

Data yang diperoleh akan dianalisis dengan analisis univariat untuk mengetahui distribusi frekuensi dan persentase dari masing-masing variabel. Setelah itu, dilakukan analisa bivariat untuk mengetahui bubungan antara faktor independen dan dependen. Analisa bivariat menggunakan tabulasi silang atau crosstab dan koefisien korelasi Phi and Cramers $V$ untuk mengetahui kuat hubungan. Interval koefisien dan kuat hubungan dapat dilihat pada Tabel 1.

Tabel 1. Koefisien Korelasi

\begin{tabular}{ll}
\hline \multicolumn{1}{c}{ Koefisien Korelasi } & \multicolumn{1}{c}{ Kuat Hubungan } \\
\hline $\mathrm{r}=0$ & Tidak ada korelasi \\
$0<\mathrm{r} \leq 0,25$ & Korelasi sangat lemah \\
$0,25<\mathrm{r} \leq 0,5$ & Korelasi cukup \\
$0,5<\mathrm{r} \leq 0,75$ & Korelasi kuat \\
$0,75<\mathrm{r} \leq 0,99$ & Korelasi sangat kuat \\
$\mathrm{r}=1$ & Korelasi sempurna \\
\hline
\end{tabular}

Sumber: Sarwono (2009)

\section{HASIL}

PT. X memiliki 24 area yang teridentifikasi sebagai confined space. Salah satu confined space yang terbesar dan frekuensi pekerjaan di dalamnya cukup sering dibandingkan lainnya adalah Ducting Dust Collector. Seluruh aktivitas di area confined space yang ada di PT. X telah memiliki Identifikasi Bahaya dan Penilaian Risiko (IBPR). Hasil identifikasi bahaya pada Ducting Dust Collector menggambarkan adanya 10 bahaya pada area tersebut, antara lain tempat sempit (potensi terbentur, terpeleset), pencahayaan kurang, ventilasi kecil (potensi lembab, pengap), ada indikasi gas, uap (potensi keracunan, sesak napas), $\mathrm{O}_{2}$ kurang dari 19,2\% atau lebih dari $23 \%$ (potensi kekurangan oksigen dan kebakaran), debu (potensi sesak napas, mata kelilipan), area kerja bising (gangguan pendengaran), miss komunikasi antar pekerja, kondisi darurat (accident, kebakaran, lampu mati), dan high area (potensi jatuh). Berdasarkan semua bahaya, 8 diantaranya berada pada tingkat risiko high/tinggi, dan 2 lainnya berada pada tingkat risiko extreme/sangat tinggi. Kedua bahaya yang dimaksud adalah ventilasi kecil (potensi lembab, pengap) dan high area (potensi jatuh).

\section{Karakteristik Individu}

Karakteristik pekerja cleaning di Ducting Dust Collector menunjukkan bahwa sebagian besar pekerja berada pada kelompok usia muda $(<38$ tahun) sebesar 52,6\%. Pendidikan terakhir responden terbanyak pada tingkat SMA, sebesar 78,9\%. Untuk masa kerja, mayoritas responden telah lama atau $>3$ tahun memiliki masa kerja di confined space yaitu sebesar $57,9 \%$.

\section{Pengetahuan}

Sebagian besar pekerja memiliki pengetahuan cukup sejumlah 10 orang $(52,6 \%)$. Pekerja yang memiliki pengetahuan baik hanya 5 orang saja $(26,3 \%)$. Sementara itu, 4 orang lainnya memiliki pengetahuan kurang $(21,1 \%)$.

\section{Sarana Prasarana}

Berdasarkan hasil observasi PT. X telah menyediakan seluruh item sarana prasarana untuk mendukung pekerja dalam menerapkan SOP bekerja di confined space. Akan tetapi, beberapa sarana memiliki jumlah yang tidak sesuai dengan kebutuhan 
pekerja. Jumlah gas detector, alat komunikasi, safety body harness dan Self-Contained Breathing Apparatus (SCBA) terbatas. Bahkan, kondisi SCBA tampak tidak terawat dan tidak layak pakai.

Hasil kuesioner menunjukkan bahwa sebagian besar pekerja $(63,2 \%)$ menyatakan sarana dan prasarana yang mendukung penerapan SOP bekerja di confined space PT. X telah tersedia.

\section{Pengawasan}

Seluruh pekerja (100\%) menyatakan pengawasan terhadap perilaku pekerja dalam menerapkan SOP bekerja di confined space PT. X sudah baik. Hal ini karena frekuensi pengawasan sudah dilakukan $>3$ kali selama pekerjaan berlangsung.

\section{Perilaku Penerapan SOP Bekerja di Confined Space}

Sebagian besar pekerja $(52,6 \%)$ telah berperilaku baik dalam menerapkan SOP bekerja di confined space PT. X. Selisih antara pekerja yang memiliki perilaku baik dan kurang baik hanya 1 orang saja $(5,2 \%)$.

Tabel 2. Distribusi Frekuensi Karakteristik Individu Pekerja di Confined Space PT. X pada April 2017

\begin{tabular}{llrc}
\hline \multicolumn{2}{c}{ Karakteristik Individu } & n & \% \\
\hline \multirow{2}{*}{ Usia } & Muda $(<38$ tahun $)$ & 10 & 52,6 \\
& Tua $(>38$ tahun $)$ & 9 & 47,4 \\
\hline \multirow{3}{*}{ Pendidikan } & SD & 2 & 10,5 \\
& SMP & 2 & 10,5 \\
& SMA & 15 & 78,9 \\
\hline \multirow{2}{*}{ Masa Kerja } & Baru ( $\leq 3$ tahun $)$ & 8 & 42,1 \\
& Lama ( $>3$ tahun $)$ & 11 & 57,9 \\
\hline
\end{tabular}

Tabel 3. Distribusi Frekuensi Pengetahuan Pekerja di Confined Space PT. X pada April 2017

\begin{tabular}{lrc}
\hline \multicolumn{1}{c}{ Pengetahuan } & n & \% \\
\hline Baik & 5 & 26,3 \\
Cukup & 10 & 52,6 \\
Kurang & 4 & 21,1 \\
\hline Total & 19 & 100,0 \\
\hline
\end{tabular}

\section{Hubungan Pengetahuan dengan Perilaku Penerapan SOP Bekerja di Confined Space}

Sebagian besar yakni $80 \%$ pekerja berpengetahuan baik memiliki perilaku baik dalam menerapkan SOP bekerja di confined space. Sebagian besar yakni $60 \%$ pekerja dengan pengetahuan cukup juga memiliki perilaku baik dalam menerapkan SOP bekerja di confined space. Seluruh pekerja dengan pengetahuan kurang memiliki perilaku penerapan SOP bekerja di confined space yang kurang baik. Hal ini menunjukkan bahwa semakin baik tingkat pengetahuan responden, maka perilaku penerapan SOP cenderung lebih baik.

Berdasarkan hasil penelitian tersebut, diperoleh nilai koefisien korelasi Cramers $V$ sebesar 0,57. Artinya, terdapat korelasi kuat antara pengetahuan dengan perilaku penerapan SOP bekerja di confined space.

\section{Hubungan Sarana Prasarana dengan Perilaku Penerapan SOP Bekerja di Confined Space}

Sebagian besar yakni $75 \%$ pekerja yang menyatakan bahwa sarana dan prasarana telah tersedia berperilaku baik dalam menerapkan

Tabel 4. Hasil Observasi Sarana Prasarana terkait Penerapan SOP Bekerja di Confined Space PT. X pada April 2017

\begin{tabular}{clcr}
\hline No & \multicolumn{1}{c}{ Item } & Ada & Tidak Ada \\
\hline 1. & Entry Permit & $\checkmark$ & \\
2. & Gas Detector & $\checkmark$ \\
3. $\quad$ Blower & $\checkmark$ \\
4. $\quad$ Alat Penerangan & $\checkmark$ \\
5. Alat Komunikasi & $\checkmark$ \\
APD (Sesuai IBPR) & \\
6. $\quad$ Safety shoes & $\checkmark$ \\
7. $\quad$ Helm & $\checkmark$ \\
8. $\quad$ Sarung Tangan & $\checkmark$ \\
9. $\quad$ Masker & $\checkmark$ \\
10. $\quad$ Kacamata safety & $\checkmark$ \\
11. $\quad$ Earplug & $\checkmark$ \\
12. $\quad$ Safety Body Harness & $\checkmark$ \\
13. $\quad$ SCBA & $\checkmark$ \\
\hline
\end{tabular}


Tabel 6. Distribusi Frekuensi Pengawasan yang Diperoleh Pekerja di Confined Space PT. X pada April 2017

\begin{tabular}{lcc}
\hline \multicolumn{1}{c}{ Pengawasan } & n & \% \\
\hline Baik & 19 & 100,0 \\
Kurang baik & 0 & 0,0 \\
\hline Total & 19 & 100,0 \\
\hline
\end{tabular}

SOP bekerja di confined space. Sebagian besar pekerja yakni $85,7 \%$ pekerja yang menyatakan sarana prasarana tidak tersedia memiliki perilaku penerapan SOP yang kurang baik. Hal ini menunjukkan bahwa ketersediaan sarana dan prasarana cenderung mendukung perilaku responden dalam menerapkan SOP bekerja di confined space dengan lebih baik. Berdasarkan hasil penelitian tersebut, diperoleh nilai koefisien korelasi Cramers $V$ sebesar 0,57. Artinya, terdapat korelasi kuat antara pengetahuan dengan perilaku penerapan SOP bekerja di confined space.

\section{Hubungan Sarana Prasarana dengan Perilaku Penerapan SOP Bekerja di Confined Space}

Sebagian besar yakni $75 \%$ pekerja yang menyatakan bahwa sarana dan prasarana telah tersedia berperilaku baik dalam menerapkan SOP bekerja di confined space. Sebagian besar pekerja yakni $85,7 \%$ pekerja yang menyatakan sarana prasarana tidak tersedia memiliki perilaku penerapan SOP yang kurang baik. Hal ini menunjukkan bahwa
Tabel 7. Distribusi Frekuensi Perilaku Penerapan SOP Bekerja di Confined Space PT. X pada April 2017

\begin{tabular}{lcc}
\hline \multicolumn{1}{c}{ Perilaku } & n & \% \\
\hline Baik & 10 & 52,6 \\
Kurang Baik & 9 & 47,4 \\
\hline Total & 19 & 100,0 \\
\hline
\end{tabular}

ketersediaan sarana dan prasarana cenderung mendukung perilaku responden dalam menerapkan SOP bekerja di confined space dengan lebih baik.

Berdasarkan hasil penelitian tersebut, diperoleh nilai koefisien korelasi Phi sebesar 0,57. Artinya, terdapat korelasi kuat antara sarana dan prasarana dengan perilaku penerapan SOP bekerja di confined space.

\section{Hubungan Pengawasan dengan Perilaku Penerapan SOP Bekerja di Confined Space}

Seluruh pekerja menyatakan bahwa pengawasan terhadap penerapan SOP bekerja di confined space sudah baik mayoritas responden juga menyatakan telah memperoleh pengawasan $>3$ kali selama bekerja. Terdapat perbedaan perilaku penerapan SOP bekerja di confined space. Sebanyak 10 orang $(52,6 \%)$ memiliki perilaku penerapan SOP baik, sedangkan 9 lainnya $(47,4 \%)$ memiliki perilaku penerapan SOP kurang baik. Sehingga dapat disimpulkan bahwa meskipun pekerja telah mendapatkan pengawasan yang baik, namun hal

Tabel 8. Hubungan antara Pengetahuan, Sarana Prasarana, dan Pengawasan dengan Perilaku Penerapan SOP Bekerja di Confined Space PT. X pada April 2017

\begin{tabular}{|c|c|c|c|c|c|c|c|}
\hline \multirow{3}{*}{ Variabel } & \multicolumn{4}{|c|}{ Perilaku } & \multirow{2}{*}{\multicolumn{2}{|c|}{ Total }} & \multirow{3}{*}{$\begin{array}{l}\text { Nilai Koefisien } \\
\text { Phi \& Cramers }\end{array}$} \\
\hline & \multicolumn{2}{|c|}{ Baik } & \multicolumn{2}{|c|}{ Kurang Baik } & & & \\
\hline & n & $\%$ & $\mathbf{n}$ & $\%$ & $\mathbf{N}$ & $\%$ & \\
\hline Pengetahuan & & & & & & & \multirow{4}{*}{0,57} \\
\hline Baik & 4 & 80,0 & 1 & 20,0 & 5 & 100,0 & \\
\hline Cukup & 6 & 60,0 & 4 & 40,0 & 10 & 100,0 & \\
\hline Kurang & 0 & 0,0 & 4 & 100,0 & 4 & 100,0 & \\
\hline \multicolumn{8}{|c|}{ Sarana Prasarana } \\
\hline Tersedia & 9 & 75,0 & 3 & 25,0 & 12 & 100,0 & \multirow[t]{2}{*}{0,57} \\
\hline Tidak tersedia & 1 & 14,3 & 6 & 85,7 & 7 & 100,0 & \\
\hline \multicolumn{8}{|l|}{ Pengawasan } \\
\hline Baik & 10 & 52,6 & 9 & 47,4 & 19 & 100,0 & \multirow[t]{2}{*}{-} \\
\hline Kurang Baik & 0 & 0,0 & 0 & 0,0 & 0 & 100,0 & \\
\hline
\end{tabular}


tersebut tidak membuat semua pekerja berperilaku menerapkan SOP bekerja di confined space dengan baik.

\section{PEMBAHASAN}

\section{Karakteristik Individu}

\section{Usia}

Berdasarkan hasil penelitian pada tabel 2 dapat dilihat bahwa sebagian besar pekerja dari total responden berusia $<38$ tahun dengan jumlah 10 pekerja $(52,6 \%)$. Sedangkan pekerja yang berada pada usia $>38$ tahun sejumlah 9 orang $(47,4 \%)$. Hanya terdapat sedikit selisih jumlah pekerja berdasarkan golongan usia.

Menurut Tarwaka (2004) dalam Setyaningsih (2009), bertambahnya usia akan diikuti dengan penurunan volume oksigen maksimal, ketajaman pendengaran dan penglihatan, kecepatan membedakan sesuatu, membuat keputusan dan kemampuan mengingat jangka panjang. Sehingga semakin tua usia pekerja, maka ia akan cenderung berperilaku tidak aman. Wicaksono (2000) menyatakan bahwa salah satu bentuk perilaku tidak aman atau substandard practice berupa pelanggaran terhadap SOP seperti yang disebutkan oleh Bird dan Germain (1992).

Pratiwi (2014) juga menyatakan bahwa usia searah dengan perilaku tidak aman. Semakin tua usia seseorang, maka semakin tinggi kategori perilaku tidak aman yang dilakukan, dan sebaliknya, semakin muda usia seseorang maka kategori perilaku tidak aman yang dilakukan semakin rendah atau bahkan masuk dalam kategori aman.

\section{Pendidikan}

Berdasarkan hasil penelitian pada tabel 1 tingkat pendidikan tertinggi yang pernah diperoleh pekerja adalah SMA. Sebagian besar pekerja yaitu 15 orang $(78,9 \%)$ mengaku memiliki pendidikan terakhir SMA. Pendidikan seseorang berpengaruh dalam pola pikir seseorang dalam menghadapi pekerjaan yang dipercayakan kepadanya. Selain itu, pendidikan juga akan mempengaruhi tingkat penyerapan terhadap pelatihan yang diberikan dalam rangka melaksanakan pekerjaan dan keselamatan kerja (Maulidhasari, 2011).

\section{Masa Kerja}

Sebagian besar pekerja telah memiliki masa kerja yang lama di bidang confined space. Hal ini dapat dilihat pada tabel 1 bahwa sebesar 11 pekerja $(57,9 \%)$ telah bekerja $>3$ tahun. Menurut Davis (1984) dalam Setyawati (2010), semakin lama masa kerja seseorang, maka akan cenderung lebih stabil emosinya sehingga dapat bekerja secara aman dan terhindar dari tindakan tidak aman saat bekerja. Hal ini dikarenakan penyesuaian dengan lingkungan yang telah berlangsung lama seiring dengan pengalaman yang didapat.

\section{Pengetahuan}

Sebagian besar pekerja memiliki pengetahuan yang cukup terkait penerapan SOP bekerja di confined space. Hal ini dapat terlihat pada tabel 3 bahwa sebanyak 10 pekerja $(52,6 \%)$ berada pada kategori pengetahuan cukup. Sedangkan, pekerja dengan pengetahuan baik hanya 5 orang saja (26,3\%). Sebagian besar pekerja telah mengetahui SOP dan manfaatnya, syarat melakukan pekerjaan di confined space, safety permit, frekuensi pengukuran atmosfer, level konsentrasi oksigen berbahaya, pengendalian selama berada di confined space, jumlah standby person, alat penunjang pekerjaan dan cara menjaga keamanan akses keluar masuk confined space.

Tidak banyak pekerja yang mengetahui potensi bahaya yang terdapat di confined space, pengendalian yang harus dilakukan apabila atmosfer berbahaya, APD berupa alat bantu pernafasan ketika memasuki confined space, dan langkah yang diambil apabila terjadi kecelakaan atau keadaan darurat di confined space.

Pengetahuan berikatan dengan perilaku yang akan ditimbulkan seseorang. Perilaku berhubungan dengan jumlah informasi yang dimiliki seseorang sebagai hasil proses penginderaan terhadap objek tertentu. Semakin sempit pengetahuan seseorang maka semakin negatif perilaku yang dilakukannya. Semakin sedikit pengetahuan seseorang tentang $\mathrm{K} 3$ di tempat kerjanya, maka peluang pekerja akan melakukan perilaku tidak aman akan semakin besar (Dzulfiqar, 2016).

\section{Sarana Prasarana}

Berdasarkan hasil penelitian pada tabel 5 dapat dilihat bahwa sebagian besar responden menyatakan 
bahwa sarana dan prasarana yang mendukung penerapan SOP bekerja di confined space telah disediakan oleh PT. X. Hasil observasi pada tabel 4 pun menunjukkan bahwa PT. X telah menyediakan sarana dan prasarana yang mendukung penerapan SOP bekerja di confined space, seperti poster, entry permit, gas detector, blower, alat penerangan, alat komunikasi, dan APD sesuai IBPR. Akan tetapi beberapa sarana prasarana belum mencukupi jumlahnya dengan kebutuhan pekerja dan ada sarana dengan kondisi yang tidak terawat.

Noviandry (2013) menyatakan ada hubungan antara ketersediaan Alat Pelindung Diri (APD) dengan perilaku penggunaan APD. Oleh karena itu, apabila ada sarana prasarana yang tidak tersedia dengan baik, maka hal ini akan menghambat perilaku pekerja dalam menerapkan SOP bekerja di confined space.

\section{Pengawasan}

Seluruh pekerja menyatakan bahwa pengawasan terhadap perilaku pekerja dalam menerapkan SOP bekerja di confined space PT. X sudah baik. Hal ini berdasarkan penelitian pada tabel 6 yang menunjukkan bahwa $100 \%$ pekerja memiliki penilaian yang baik mengenai pengawasan selama bekerja di confined space PT. X. Pengawasan pekerjaan di confined space PT. X dilaksanakan setiap 2-3 hari sekali oleh seorang petugas SHE. Menurut pekerja, frekuensi pengawasan yang diperoleh selama pekerjaan berlangsung sudah $>3$ kali.

Setelah dilakukan penelitian, fakta yang diperoleh adalah petugas mengawasi dari bawah confined space saja. Pekerjaan cleaning di Ducting Dust Collector berada di ketinggian. Apabila ditemukan perilaku pekerja yang tidak sesuai SOP atau berpotensi membahayakan keselamatan pekerja, maka petugas akan berteriak untuk mengingatkan pekerja. Pengawasan yang dilakukan sudah rutin, namun metode yang dipakai kurang efektif.

Menurut Saragih (2014), adanya pengawasan diperlukan untuk mengubah perilaku pekerja. Pelaksanaan pengawasan yang rutin akan mendorong motivasi pekerja untuk berperilaku aman. Adanya pengawasan dapat mengingatkan pekerja untuk selalu bekerja dengan baik dan benar serta berperilaku aman. Sebaliknya, apabila pelaksanaan pengawasan tidak dilakukan secara rutin maka pekerja akan merasa bebas dalam melakukan pekerjaan dan menjadi tidak tahu apakah pekerjaannya telah dilakukan secara benar dan aman atau tidak sehingga pekerja cenderung akan berperilaku tidak aman.

\section{Perilaku Penerapan SOP Bekerja di Confined Space}

Standar Operasional Prosedur merupakan suatu bentuk peraturan, seperti ungkapan Geller (2001) bahwa peraturan merupakan dokumen tertulis yang mendokumentasikan standar, norma, dan kebijakan untuk perilaku yang diharapkan. Ungkapan Geller tersebut dapat dimaknai bahwa SOP juga berisi perilaku yang harus dilakukan untuk menjalankan suatu pekerjaan. Menurut Reason (2008), kesalahan dalam mematuhi SOP merupakan kesalahan dan suatu pelanggaran. Seperti yang telah dijelaskan oleh Wicaksono (2000) bahwa pelanggaran terhadap SOP merupakan salah satu bentuk perilaku tidak aman atau substandard practice seperti yang disebutkan oleh Bird and Germain (1992).

Berdasarkan hasil penelitian yang telah dilakukan, dapat dilihat pada Tabel 7 yang menunjukkan bahwa sebagian besar dari total responden 19 orang terdapat 10 pekerja $(52,6 \%)$ telah berperilaku baik dalam menerapkan SOP bekerja di confined space PT. X. Hanya selisih satu orang jika dibandingkan dengan jumlah pekerja yang memiliki perilaku kurang baik dalam menerapkan SOP bekerja di confined space PT. X, yakni 9 orang $(47,4 \%)$.

Perilaku kurang baik pekerja dalam menerapkan SOP bekerja di confined space dapat terlihat dari pekerja yang tidak menggunakan safety body harness dan Self Contained Breathing Apparatus (SCBA) selama bekerja di confined space. Padahal safety body harness dan Self Contained Breathing Apparatus (SCBA) termasuk upaya pengendalian risiko dalam tabel Identifikasi Bahaya dan Penilaian Risiko (IBPR) aktivitas di area confined space Ducting Dust Collector.

Berdasarkan Pedoman Keselamatan dan Kesehatan Kerja di Ruang Terbatas atau Confined Spaces (2006), apabila udara di dalam ruangan berbahaya atau beracun, maka pekerja membutuhkan pasokan udara bersih dan segar saat memasuki dan berada di dalamnya. Alat bantu pernapasan dengan tangki udara yang mampu memasok udara bersih melalui selang yaitu Self-Contained Breathing Apparatus (SCBA). Meskipun Ducting Dust Collector tidak berisi cairan atau gas beracun, melainkan debu akibat proses produksi. Namun, 
pekerjaan yang dilakukan di dalam area terbatas tersebut tetap membutuhkan pasokan udara bersih dan segar. Mengingat risiko bahaya keselamatan dan kesehatan yang dihadapi pekerja confined space berupa bahaya atmosfer.

Bahaya atmosfer yang dimaksud seperti hasil Identifikasi Bahaya dan Penilaian Risiko (IBPR) aktivitas di area Ducting Dust Collector yang telah dilakukan oleh PT. X meliputi ventilasi kecil (potensi lembab, pengap), ada indikasi gas, uap (potensi keracunan, sesak napas), $\mathrm{O}_{2}$ kurang dari $19,2 \%$ atau lebih dari 23\% (potensi kekurangan oksigen dan kebakaran).

Selain itu, konfigurasi Ducting Dust Collector merupakan confined space yang berada di ketinggian. Perilaku pekerja yang tidak menggunakan body harness selama bekerja bertentangan dengan Permenakertrans RI No. 9 Tahun 2016 yang menyatakan bahwa tenaga kerja wajib menggunakan perangkat pencegah jatuh perorangan yang paling sedikit terdiri atas sabuk tubuh (full body harness) dan tali pembatas gerak (work restraint). Melihat konfigurasi Ducting Dust Collector yang berupa pipa besar berlaku pada ketinggian, sedangkan pekerja bekerja tanpa body harness, hal ini meningkatkan kemungkinan dan keparahan terjadinya kecelakaan kerja. Serta mempersulit evakuasi atau proses penyelamatan apabila pekerja jatuh di dalam confined space.

\section{Hubungan Pengetahuan dengan Perilaku Penerapan SOP Bekerja di Confined Space}

Pada Tabel 8 menunjukkan bahwa semakin baik tingkat pengetahuan responden, maka perilaku penerapan SOP cenderung lebih baik. Berdasarkan hasil penelitian tersebut, diperoleh nilai koefisien korelasi Cramers $V$ sebesar 0,57. Apabila dibandingkan dengan tabel 1 tentang koefisien korelasi, maka nilai tersebut menunjukkan bahwa hubungan antara pengetahuan dengan perilaku penerapan SOP bekerja di confined space memiliki korelasi yang kuat. Terbukti dengan besarnya persentase pekerja ( $80 \%$ ) yang berpengetahuan baik dan berperilaku baik dalam menerapkan SOP bekerja di confined space. Serta, seluruh pekerja (100\%) yang berpengetahuan kurang terbukti memiliki perilaku penerapan SOP yang kurang baik.

Hasil penelitian ini didukung oleh penelitian Judha (2012) yang menyatakan bahwa terdapat hubungan antara pengetahuan dengan kepatuhan SOP. Hasil penelitian Judha (2012) menyatakan bahwa pengetahuan yang baik berpeluang lebih besar untuk patuh terhadap SOP dibandingkan dengan yang berpengetahuan kurang. Hal tersebut sesuai dengan teori perilaku dalam Notoatmodjo (2014) yang menyatakan bahwa pengetahuan merupakan salah satu determinan perilaku dalam faktor predisposisi yang akan menentukan perilaku individu. Oleh karena itu, pekerja dengan pengetahuan SOP yang baik dapat mencegah terjadinya kecelakaan kerja baik pada dirinya maupun orang lain dengan menerapkan SOP yang ada.

Seperti yang diungkapkan oleh Bird and Germain (1992) bahwa kurangnya pengetahuan menjadi salah satu penyebab dasar kecelakaan. Heinrich (1931) dalam HaSPA (2012) juga menyatakan bahwa kurangnya pengetahuan merupakan sebab munculnya perilaku tidak aman yang dapat menyebabkan kecelakaan kerja.

Menurut Bloom (1908) dalam Notoatmodjo (2010), pengetahuan seseorang terhadap suatu objek memiliki tingkatan yang berbeda. Tingkatan tersebut terbagi dalam 6 tingkatan, yaitu tahu (know), memahami (comprehension), aplikasi (application), analisis (analysis), sintesis (synthesis), dan evaluasi (evaluation).

Berdasarkan hasil penelitian pada pekerja cleaning Ducting Dust Collector PT. X, pengetahuan merupakan faktor yang memiliki hubungan kuat dengan perilaku penerapan SOP bekerja di confined space. Hal ini mungkin terjadi karena pekerja telah sampai pada tahap aplikasi. Sehingga, pekerja bekerja di confined space sesuai dengan SOP yang tersedia berdasarkan pengetahuannya.

Hal lain yang mungkin adalah pekerja telah memperoleh pengetahuan berdasarkan pengalaman dan pelatihan yang telah ia dapatkan dari tempat kerja sebelumnya. Selain itu, toolbox meeting yang diberikan petugas SHE sebelum pekerja memulai pekerjaan di confined space membantu pekerja mengingat kembali mengenai pengetahuan yang telah ia miliki.

\section{Hubungan Sarana Prasarana dengan Perilaku Penerapan SOP Bekerja di Confined Space}

Pada tabel 8 menunjukkan bahwa ketersediaan sarana dan prasarana cenderung mendukung perilaku responden dalam menerapkan SOP dengan lebih baik. Berdasarkan hasil penelitian tersebut, diperoleh nilai koefisien korelasi Phi sebesar 0,57. Apabila dibandingkan dengan tabel 1 tentang koefisien korelasi, maka nilai tersebut menunjukkan bahwa hubungan antara sarana dan prasarana dengan 
perilaku penerapan SOP bekerja di confined space memiliki korelasi yang kuat. Hasil penelitian ini sejalan dengan penelitian Noviandry (2013) yang menyatakan ada hubungan antara ketersediaan Alat Pelindung Diri (APD) dengan perilaku penggunaan APD.

Berdasarkan hasil observasi sarana dan prasarana yang mendukung penerapan SOP bekerja di confined space, PT. X telah menyediakan poster, entry permit, gas detector, blower, alat penerangan, alat komunikasi, dan APD sesuai IBPR. Jumlah beberapa sarana yang disediakan tidak sesuai dengan jumlah pekerja, seperti alat penerangan, alat komunikasi, dan APD. PT. X juga telah menyediakan full body harness. Seluruh pekerja mengaku tidak menggunakan body harness selama melakukan pekerjaan cleaning di Ducting Dust Collector. Pekerja merasa tidak perlu menggunakannya karena akses menuju manhole tidak terlalu tinggi dan pihak SHE PT. X mengiyakan hal tersebut. Pihak SHE PT.X menyatakan pekerja boleh tidak menggunakan body harness, karena berdasarkan hierarki pengendalian APD merupakan opsi paling akhir, setidaknya telah ada barrier/penghalang jatuh di jalanan sepanjang Ducting Dust Collector. Selain itu, ada pula sarana dengan kondisi tidak terawat sehingga tidak dapat terpakai, seperti APD berupa SCBA.

Confined space merupakan tempat kerja dengan risiko tinggi. Perusahaan seharusnya menyediakan APD sesuai dengan risiko yang ada di tempat kerja dan dalam jumlah yang cukup untuk pekerja sesuai 63 dengan Undang-undang nomor 1 tahun 1970 tentang Keselamatan Kerja pasal 14 butir c yang berbunyi "Menyediakan secara cuma-cuma, semua alat perlindungan diri yang diwajibkan pada tenaga kerja yang berada di bawah pimpinannya dan menyediakan bagi setiap orang lain yang memasuki tempat kerja tersebut, disertai dengan petunjukpetunjuk yang diperlukan menurut petunjuk pegawai pengawas atau ahli keselamatan kerja”.

Walaupun pekerja menyatakan bahwa PT. X telah menyediakan sarana dan prasarana untuk mendukung perilaku mereka dalam menerapkan SOP bekerja di confined space, namun hasil penelitian menggambarkan jumlah sarana yang tersedia masih belum sesuai dengan kebutuhan pekerja. Sehingga, terdapat kesenjangan sarana dan prasarana yang tersedia berdasarkan hasil kuesioner pada pekerja cleaning di Ducting Dust Collector. Pekerja yang memperoleh sarana dan prasarana lebih lengkap cenderung memiliki perilaku penerapan SOP yang lebih baik, dibanding pekerja yang memperoleh sarana dan prasarana lebih sedikit.

Hasil penelitian ini sesuai dengan teori perilaku yang menyatakan bahwa ketersediaan sarana dan prasarana merupakan salah satu determinan perilaku dalam faktor enabling yang akan menentukan perilaku individu (Notoatmojo, 2014).

\section{Hubungan Pengawasan dengan Perilaku Penerapan SOP Bekerja di Confined Space}

Pada tabel 8 menunjukkan bahwa meskipun pekerja telah mendapatkan pengawasan yang baik, namun hal tersebut tidak membuat semua pekerja berperilaku menerapkan SOP bekerja di confined space dengan baik. Hasil penelitian tersebut sejalan dengan hasil penelitian Saragih dkk (2014) yang menunjukkan tidak ada hubungan yang signifikan antara pengawasan dengan tindakan tidak aman.

Hasil penelitian ini tidak sesuai dengan teori perilaku yang menyatakan bahwa pengawasan merupakan salah satu determinan perilaku dalam faktor reinforcing yang akan menentukan perilaku individu (Notoatmojo, 2014). Pengawasan merupakan antesenden dalam teori ABC. Seperti yang diungkapkan Fleming, M. \& R. Lardner (2002) bahwa keberadaan antesenden memang diperlukan untuk memicu perilaku. Akan tetapi, adanya antesenden tidak menjamin munculnya suatu perilaku.

Pengawasan dilakukan untuk memastikan bahwa tujuan dan target sesuai dengan kebutuhan, memastikan pekerja dapat menanggulangi kesulitan yang mereka temui, meningkatkan motivasi, membantu meningkatkan keterampilan dan kemampuan (Geller, 2001). Menurut Halimah (2010), peran pengawas merupakan faktor yang paling dominan yang berhubungan dengan perilaku pekerja.

Pengawasan pekerjaan di confined space dilakukan oleh pihak SHE PT. X. Berdasarkan penelitian, seluruh pekerja menyatakan bahwa pengawasan yang diberikan sudah baik. Oleh karena itu, konsistensi pengawasan yang baik tersebut perlu dipertahankan. Hal ini karena pengawasan yang kurang baik merupakan kegagalan latent dalam sebuah sistem organisasi yang apabila dibiarkan akan menjadi pemicu timbulnya kecelakaan (Reason dalam HaSPA, 2012). Bird and Germain (1992) juga menyatakan bahwa kurang baiknya suatu pengawasan dapat menyebabkan terjadinya kecelakaan. 
Pengawasan pekerjaan di confined space PT. X dilaksanakan setiap 2-3 hari sekali oleh seorang petugas SHE. Setelah dilakukan penelitian, fakta yang diperoleh adalah petugas mengawasi dari bawah confined space saja. Pekerjaan cleaning di Ducting Dust Collector berada di ketinggian. Apabila ditemukan perilaku pekerja yang tidak sesuai SOP atau berpotensi membahayakan keselamatan pekerja, maka petugas akan berteriak untuk mengingatkan pekerja.

Pengawasan yang dilakukan sudah rutin, namun metode yang dipakai kurang efektif. Oleh sebab itu, adanya pengawasan tidak menjamin perilaku pekerja selalu menerapkan SOP bekerja di confined space dengan baik. Akan tetapi, hal tersebut bukan berarti pengawasan tidak diperlukan untuk mengubah perilaku pekerja, justru sebaliknya pelaksanaan pengawasan yang rutin akan mendorong motivasi pekerja untuk berperilaku sesuai SOP yang tersedia.

Meskipun dalam penelitian ini, pengawasan tidak memiliki hubungan dengan perilaku pekerja dalam menerapkan SOP bekerja di confined space. Namun, pengawasan yang baik, berkelanjutan, dan terus menerus tetap harus dilakukan selama pekerjaan berlangsung, mengingat tingginya risiko pekerjaan di confined space. Seperti ungkapan Suma'mur (2009) bahwa pengawasan yang dilakukan secara berkelanjutan dan terus menerus akan mempertahankan kualitas pelaksanaan keselamatan dan upaya pencegahan kecelakaan.

\section{SIMPULAN}

Hasil penelitian menunjukkan bahwa sebagian besar pekerja telah berperilaku baik dalam menerapkan SOP bekerja di confined space. Berdasarkan nilai koefisien korelasi $P h i$ and Cramers $V$ diketahui bahwa faktor yang memiliki hubungan kuat dengan perilaku penerapan SOP bekerja di confined space adalah pengetahuan $(0,57)$ dan sarana prasarana $(0,57)$. Sedangkan, pengawasan tidak memiliki hubungan dengan perilaku penerapan SOP bekerja di confined space.

\section{DAFTAR PUSTAKA}

Bird FE., and Germain GL., 1992. Practical Loss Control Leadership. USA: International Loss Control Institute.
Direktorat Pengawasan Norma Keselamatan Kesehatan Kerja. 2006. Pedoman Keselamatan dan Kesehatan Kerja di Ruang Terbatas (Confined Space). Jakarta: Kementerian Tenaga Kerja dan Transmigrasi.

Dwihardo, Nelman dan W. Angih., 2011. Pengaruh Pelatihan, Penerapan SOP, Reward Sistem, Lingkungan Kerja dan Peralatan Kerja terhadap Produktivitas Kerja Teknisi. Skripsi. Makassar: Universitas Hasanudin.

Dzulfiqar, Amris., 2016. Faktor-Faktor yang Berhubungan dengan Perilaku Keselamatan pada Pekerja Bengkel Las di Wilayah Pejompongan Kelurahan Bendungan Hilir Jakarta Pusat. Skripsi. Jakarta: Universitas Esa Unggul.

Fishwick, Tony., 2012. Recurring Accidents: Confined Space. A New Series of Articles Inspired by IChemE's Loss Prevention Bulletin and The BP Process Safety Series: Sharing Lessons Learned From Accidents.

Fleming, M. \& R. Lardner., 2002. Strategies to Promote Safe Behavior as Part of a Health and Safety Management System. Norwich, Health, and Safety Executive. www.hse.gov.uk/research/ cr_pdf/2002/crr02430.pdf [Sitasi 3 April 2017]

Geller, E Scott., 2001. The Psychology of Safety Handbook. New York: Lewis Publishers.

Halimah, Siti., 2010. Faktor-Faktor yang Memengaruhi Perilaku Aman Karyawan di Area Produksi PT. SIM Plant Tambun II Tahun 2010. Skripsi. Jakarta: Universitas Islam Negeri Syarif Hidayatullah.

HaSPA (Health and Safety Professionals Alliance). 2012. The Core Body of Knowledge for Generalist OHS Professionals: Model of Causation: Safety. Tullamarine, VIC: Safety Institute of Australia.

Judha, M., 2012. Hubungan Tingkat Pengetahuan Perawat dengan Kepatuhan dalam Pelaksanaan SOP Pemasangan Kateter Urin di Bangsal Rawat Inap RSUD Panembahan Senopati Bantul. Skripsi. Surakarta: Stikes Kusuma Husada.

Maulidhasari., 2011. Faktor-Faktor yang Berhubungan dengan Perilaku Berbahaya (Unsafe Action) Pada Bagian Unit Intake PT. Indonesia Power Unit Bisnis Pembangkitan (UBP). JURNAL VISIKES. Vol. 10, No. 1.

Notoatmodjo, Soekidjo., 2014. Ilmu Perilaku Kesehatan. Jakarta: Rineka Cipta.

Noviandry, Ilham., 2013. Faktor-Faktor yang Berhubungan dengan Perilaku Pekerja dalam 
Penggunaan Alat Pelindung Diri (APD) pada Industri Pengelasan Informal di Kelurahan Gondrong, Kecamatan Cipondoh, Kota Tangerang. Skripsi. Jakarta: Universitas Islam Negeri Syarif Hidayatullah.

OSHA., 2004. Permit Required Confined Space. United State: U.S Departemen of Labor.

Pettit, T.A. \& R. Bradde., 1994. Overview of Confined Space Hazards. In: NIOSH. Worker Deaths in Confined Space - A Summary of NIOSH Surveillance and Investigative Findings. United State: U.S Department of Health and Human Services.

Pratiwi, OR., 2014. Analisis Faktor Karakteristik Individu yang Berhubungan dengan Tindakan Tidak Aman Pada Tenaga Kerja di Perusahaan Konstruksi Baja. The Indonesian Journal of Occupational Safety and Health. Vol. 3 No. 2: 190.

Reason, J., 2008. The Human Contribution: Unsafe Act, Accident and Heroic Recoveries. USA: Ashgate.

Saragih, Feddy RP. dkk., 2014. Faktor-Faktor yang Berhubungan dengan Tindakan tidak Aman pada
Pekerja Lapangan PT. Telkom Cabang Sidikalang Kabupaten Dairi. Skrispi. Medan: Universitas Sumatera Utara.

Sarwono, Jonathan., 2009. Statistik itu Mudah: Panduan Lengkap untuk Belajar Komputerisasi Statistik Menggunakan SPSS 16. Yogyakarta: Andi.

Setyaningsih, Ririn., 2009. Hubungan Antara Getaran Mesin dengan Kelelahan pada Pekerja Bagian Moulding Industri Pengolahan Kayu Brumbung Perum Perhutani Unit I Jawa Tengah. Skripsi. Semarang: Universitas Negeri Semarang.

Setyawati, L., 2010. Selintas Tentang Kecelakaan Kerja. Yogyakarta: Amara Books.

Suma'mur., 2009. Higiene Perusahaan Keselamatan Kerja dan Pencegahan Kecelakaan. Jakarta: $\mathrm{CV}$. Haji Masagung.

Wicaksono, DT., 2014. Penyebab Terjadinya Substandard Practice Berdasarkan Teori Loss Causation Model Pada Pengelas di PT. Bangun Sarana Baja. The Indonesian Journal of Occupational Safety and Health. Vol. 1, No. 1: 9 . 